\title{
Particulate debris from a titanium metal prosthesis induces genomic instability in primary human fibroblast cells
}

\author{
N Coen*,', MA Kadhim ${ }^{2}$, EG Wright ${ }^{3}$, CP Case $^{4}$ and CE Mothersill' \\ 'Radiation and Environmental Science Centre, Dublin Institute of Technology, Kevin St, Dublin 8, Ireland; ${ }^{2}$ Radiation and Genome Stability Unit, Medical \\ Research Council, Harwell, Didcot, Oxon OXII ORD, UK; ${ }^{3}$ Department of Molecular and Cellular Pathology, Ninewells Hospital and Medical School, \\ University of Dundee, Dundee, DDI 9SY, UK; ${ }^{4}$ Avon Orthopaedic Centre, Southmead Hospital, Bristol BSIO 5NB, UK
}

Previous studies detected both lethal and cumulative chromosomal aberrations in bone marrow and peripheral blood of patients with worn hip and knee replacements. This study shows that wear debris from a worn titanium metal on high-density polyethylene hip replacement also produces chromosomal instability and reproductive failure in cell culture. The progeny of these treated cells also displayed chromosomal instability, mainly consisting of chromatid breaks and minutes, and reproductive failure as determined by clonogenic survival many generations postexposure. These delayed effects are similar to those caused by the heavy metals cadmium and nickel and to those seen for low-dose radiation. These findings may have important implications with regard to the long-term risks of joint replacement surgery. This highlights the need for long-term epidemiological studies of patients with surgical implants. British Journal of Cancer (2003) 88, 548-552. doi: I0.I038/sj.bjc.6600758 www.bjcancer.com

(C) 2003 Cancer Research UK

Keywords: hip implants; genomic instability; chromosome aberrations; delayed reproductive death

Prosthetic joint replacement is a common surgical procedure with at least 1 million hip prosthesis being implanted each year, worldwide (Bullough, 1994). Prosthetic joint replacements are typically trouble free; however, approximately $20 \%$ fail within 10 years (Saeed and Revell, 2001). The expectations for this procedure continue to rise as it is being extended to younger and more active patients whose life expectancy exceeds 30 years postsurgery (Jacobs et al, 1998). These metal prostheses undergo corrosion in the body (Merritt and Brown, 1996; Jacobs, 1999). With the passage of time, this can result in the generation of particulate debris that can accumulate in the tissues adjacent to the prosthesis (Case et al, 1994; Jacobs et al, 1996). Particulate debris has also been shown to accumulate in the lymph nodes, liver, spleen and bone marrow (Langkamer et al, 1993; Case et al, 1994; Jacobs, 1998), and subsequently may elicit important biological responses. Inflammatory responses have been shown to be initiated by particulate debris and they have been implicated in the induction of osteolysis through macrophage activation (Maloney et al, 1993; Jacobs et al, 1998). This appears to play a role in implant failure (Breen and Stoker, 1993). These studies indicate that particulate debris is not biologically inert. Owing to its of its superior mechanical properties and biocompatibility, titanium is widely used for joint prostheses. Titanium alloys 'in vivo' form a stable oxide layer, which greatly enhances the inertness of titanium. However, because of mechanical and biological disturbance the destabilisation of this oxide layer is inevitable leading to the release of titanium ions and particulate debris (Breen and Stoker, 1993).

Past studies have placed their attention on prosthetic loosening, implant failure and inflammatory response. They have ignored the consideration of the long-term consequences of debris on cellular

*Correspondence: Dr N Coen; E-mail: Natasha.Coen@DIT.ie Received 13 May 2002; revised 12 November 2002; accepted 19 November 2002 viability and the induction of genomic instability. Genomic instability is a phenomenon and has definitively been shown to occur postirradiation (Kadhim et al, 1992; O’Reilly et al, 1994; Seymour et al, 1996). It has also been shown by our group to be induced by heavy metals and other environmental toxins (Mothersill et al, 1998; Coen et al, 2001). Genomic instability can manifest itself in many ways including lethal mutation/delayed reproductive death (Seymour et al, 1986; Mothersill et al, 1995; Mothersill et al, 1998), delayed appearance of nonclonal chromosomal aberrations in progeny of exposed cells (Kadhim et al, 1992, 1995) and delayed apoptosis (Lyng et al, 1996). These are regarded as delayed effects resulting from transmission of genomic instability to the progeny of treated cells. Characteristically, it is induced at frequencies greater than that of natural spontaneous mutations (Kadhim et al, 1996). Once induced, genomic instability is effectively permanent and has been shown to persist in vitro and in vivo for many cell doublings (Seymour et al, 1986; O'Reilly et al, 1994; Watson et al, 1996). The phenomenon of aneuploidy and its relevance to the genetic instability of cancer cells has recently been documented (Duesberg et al, 1998). In a study by Doherty et al (2001), a five-fold increase in aneuploidy was observed in patients with titanium-vanadium-aluminium (TiVaAl) prosthesis at revision surgery compared with those at primary arthroplasty. While the induction of genomic instability by environmentally relevant concentrations of metals has been documented, its induction by metal devices has not been studied.

The generation of particles from a metal prostheses, which considerably increases the surface area exposed, favours the release of ions that could influence cellular response of the patient to the implant (Merritt and Brown, 1996; Jacobs et al, 1998). This paper investigates the induction of genomic instability and tetraploidy by particulate titanium debris generated from a metal prosthesis. This study may highlight that at revision surgery although the stimulus may be removed the effect can persist. As there are many concerns about the adverse biological responses 
that could occur during the long term in patients with metal prosthesis, there is the need for more extensive cohort studies to be established. The end points of genomic instability used in this study were lethal mutations/delayed reproductive death and delayed cytogenetic abnormalities in the progeny of cells that were exposed to the debris.

\section{MATERIALS AND METHODS}

\section{Cell culture}

The cells used in this study were early passage, normal human fibroblasts (HF19 cells). These cells have been well characterised for the cytogenetic and survival end points used in this study and have the advantage of a normal karyotype (Kadhim et al, 1997). For these experiments, passage 4 cells were removed from liquid nitrogen storage and resuspended in $3 \mathrm{ml}$ minimum essential medium, alpha modified (Sigma Aldrich, UK), supplemented with $10 \%$ foetal calf serum (Sigma, Aldrich, UK), $2 \mathrm{~mm}$ L-glutamine, $50 \mathrm{IU} \mathrm{ml}^{-1}$ penicillin and $50 \mu \mathrm{g} \mathrm{ml}^{-1}$ streptomycin. The cells were cultured in an atmosphere of $5 \% \mathrm{CO}_{2}$ in a $24 \mathrm{~cm}^{2}$ tissue culture flask (Nunc; T24) at $37^{\circ}$ until confluent. The cell number was then expanded to provide sufficient cells for all planned experiments. Passage 5 cells were used for all experiments.

\section{Titanium debris}

Wear debris was extracted from periprosthetic tissue of a patient undergoing revision total hip arthroplasty. According to methods described by Doherty et al (2002), this tissue from a patient with TiVaAl prosthesis was digested in $1 \%$ trypsin-collagenase gently mixed and incubated at $37^{\circ} \mathrm{C}$ for $24 \mathrm{~h}$. Wear debris was separated from digested tissue on histoplaque (Sigma, Aldrich, UK) by centrifuging for $25 \mathrm{~min}$ at 3500 r.p.m. The metal layer was removed, washed in PBS, and then resuspended in PBS and stored at $-20^{\circ} \mathrm{C}$. This was the stock solution and contained approximately $6.4 \mathrm{~g}$ of metal in $1 \mathrm{ml}$ of PBS. From this dense solution of titanium debris a series of dilutions were made using dilution factors ranging from $1: 50$ to $1: 100,000$. These dilutions were made up in cell culture media. The particle suspensions were continually mixed to maintain uniform particle distribution at the time of dispersal onto cells.

\section{Cytogenetic analysis}

$5 \times 10^{5}$ cells, plated in $75 \mathrm{~cm}^{2}$ tissue culture flasks, were allowed to attach for several hours. These were then exposed to $0,1: 50000$, $1: 5000$, and 1:500 dilution factor of titanium debris for a period of $24 \mathrm{~h}$. The cells that received 0 dose of titanium debris represent control cells. After $24 \mathrm{~h}$ the cells were washed twice with PBS to remove all debris and $10 \mathrm{ml}$ of fresh growth medium was added. After $48 \mathrm{~h}$ postexposure to the titanium debris (approximately three population doublings), cells were harvested for cytogenetic analysis to examine the initial effects caused by titanium debris. The delayed effects were assessed at passage 2 (approximately 10 population doublings postexposure). Chromosome preparations were made by accumulating metaphases in the presence of $0.05 \mu \mathrm{g} \mathrm{ml}^{-1}$ colcemid for $2 \mathrm{~h}$, followed by treatment with $0.5 \%$ $\left(\mathrm{wv}^{-1}\right)$ potassium chloride and fixation in methanol:acetic acid $\left(3: 1 \mathrm{vv}^{-1}\right)$. Fixed cells were spread on to slides and air dried. These were then stained using $5 \%$ Giemsa. A minimum of 100 wellspread metaphases was scored per dose point to determine the frequency of aberrations.

\section{Clonogenic analysis}

HF19 cells were plated in $24 \mathrm{~cm}^{2}$ flasks (Nunc, Denmark) at dilutions adjusted to yield approximately 100 viable colonies according to the method established by Puck and Marcus (1956). Cultures were established in $3 \mathrm{ml}$ of growth medium and cells were allowed to attach. After attachment cultures were initiated with a range of titanium debris dilution factors, $0,1: 100000,1: 50000$, $1: 10000,1: 5000,1: 1000,1: 500,1: 100,1: 50$, for a period of $24 \mathrm{~h}$. Six flasks of cells were exposed to each dilution, three of these were stained using carbol fuchsin (Ziehl Niehlson; 20\%) to assess initial colony formation. The cells in the remaining flasks were grown and passaged to allow examination of effects in distant progeny according to the methods described by Seymour et al (1986). Delayed death was assayed at passage 2, approximately 15 population doublings postexposure to the debris.

\section{Statistical analysis}

All experiments were repeated three times and within each experiment points were set up in triplicate. Results are expressed as the mean \pm s.e. Fisher's exact test was performed on the cytogenetic results where treatments were compared to controls.

\section{RESULTS}

\section{Cytogenetic analysis}

Chromosomal instability has been defined as the persistence of nonclonal chromosomal aberrations with a high frequency of chromatid-type aberrations in the clonal descendants of a single treated cell. It is evident from this study that the induction and transmission of chromosomal instability in the progeny of primary human fibroblasts occurs as a result of exposure to titanium debris (Table 1). In cultures treated with 1:50000 and 1:5000 dilution factors of titanium debris, the induction of unstable aberrations was low compared to cultures treated with 1:500 dilution. This indicates a dose-response of the cells to increased concentrations of the particulate titanium debris. The most frequently encountered aberrations are of the unstable type (chromatid breaks, chromosome fragments and minutes), but other aberrations were also evident such as chromosome and chromatid gaps and chromosome breaks. These aberrations were evident after 15 population doublings, with a greater frequency of aberrations expressed in the progeny than in the initially treated cells. The cytogenetic analysis also demonstrated an increased expression of tetraploidy in all the various dilutions analysed. This expression of tetraploidy was most evident after exposure to 1:500 dilution factor of titanium debris. The induction of endoreduplication is also evident from the results (Table 1). Endoreduplication is where the cell undergoes two mitosis without cell division intervening (Aardema et al, 1998).

\section{Clonogenic analysis}

Figure 1 shows the initial toxicity of HF19 cells treated with titanium debris for $24 \mathrm{~h}$. The most dilute concentrations of titanium debris, $1: 100000$ and $1: 50000$, have little effect on the reproductive integrity of the cells, reducing the cloning efficiency only by $10 \%$. Concentrations greater than 1:50 000 cause a drop in clonogenic survival. The results for delayed reproductive death in the progeny of these cells correspond to 10 population doublings postexposure. These cells have not been treated with titanium debris but are the progeny of the initially treated cells. These data demonstrate that at the sublethal concentrations of titanium debris, determined from the initial toxicity, the reproductive survival is greatly reduced. At dilution factor $1: 10000$, the progenitor population that received the titanium debris showed survival of $70 \%$ but the progeny of these cells express a reduced colony formation of less than $30 \%$ of that found for the untreated control progeny. 
Table I The cytogenetical analysis of HFI9 cells postexposure to a range of dilutions containing titanium debris

\begin{tabular}{|c|c|c|c|c|c|c|}
\hline Dilution & $\begin{array}{c}\text { Population } \\
\text { doublings }\end{array}$ & $\begin{array}{l}\text { No. of } \\
\text { aberration }\end{array}$ & $\begin{array}{l}\text { No. of unstable } \\
\text { aberration }\end{array}$ & $\begin{array}{l}\text { No. of other } \\
\text { aberration }\end{array}$ & $\begin{array}{l}\text { No. of tetraploid } \\
\text { cells }\end{array}$ & Endoreduplication \\
\hline c & $\begin{array}{r}3 \\
15\end{array}$ & $\begin{array}{l}1 \\
2\end{array}$ & $\begin{array}{l}0 \\
1\end{array}$ & । & $\begin{array}{l}0 \\
3\end{array}$ & $\begin{array}{l}4 \\
0\end{array}$ \\
\hline I:50000 & $\begin{array}{r}3 \\
15\end{array}$ & $\begin{array}{l}7 \\
9\end{array}$ & $\begin{array}{l}3 \\
5\end{array}$ & $\begin{array}{l}4 \\
4\end{array}$ & $\begin{array}{l}7^{\mathrm{a}} \\
5\end{array}$ & $\begin{array}{l}9 \\
0\end{array}$ \\
\hline $1: 500$ & $\begin{array}{r}3 \\
15\end{array}$ & $\begin{array}{l}14^{\mathrm{b}} \\
20^{\mathrm{b}}\end{array}$ & $\begin{array}{r}8^{\mathrm{b}} \\
10^{\mathrm{a}}\end{array}$ & $\begin{array}{c}6 \\
10^{\mathrm{a}}\end{array}$ & $\begin{array}{l}11^{\mathrm{b}} \\
10^{\mathrm{a}}\end{array}$ & $\begin{array}{l}5 \\
0\end{array}$ \\
\hline
\end{tabular}

The results reflect aberrations out of 100 well-spread metaphases, which were scored for each treatment. There are high incidences of unstable aberrations, which include chromatid breaks, fragments and minutes, as compared to control. Other aberrations were also observed, including chromatid and chromosome gaps, chromosome breaks and acentrics. Endoreduplication and tetraploidy both showed increased incidences. ${ }^{a} P \leqslant 0.05 .{ }^{b} P<0.005$ as determined by the Fisher's exact test.

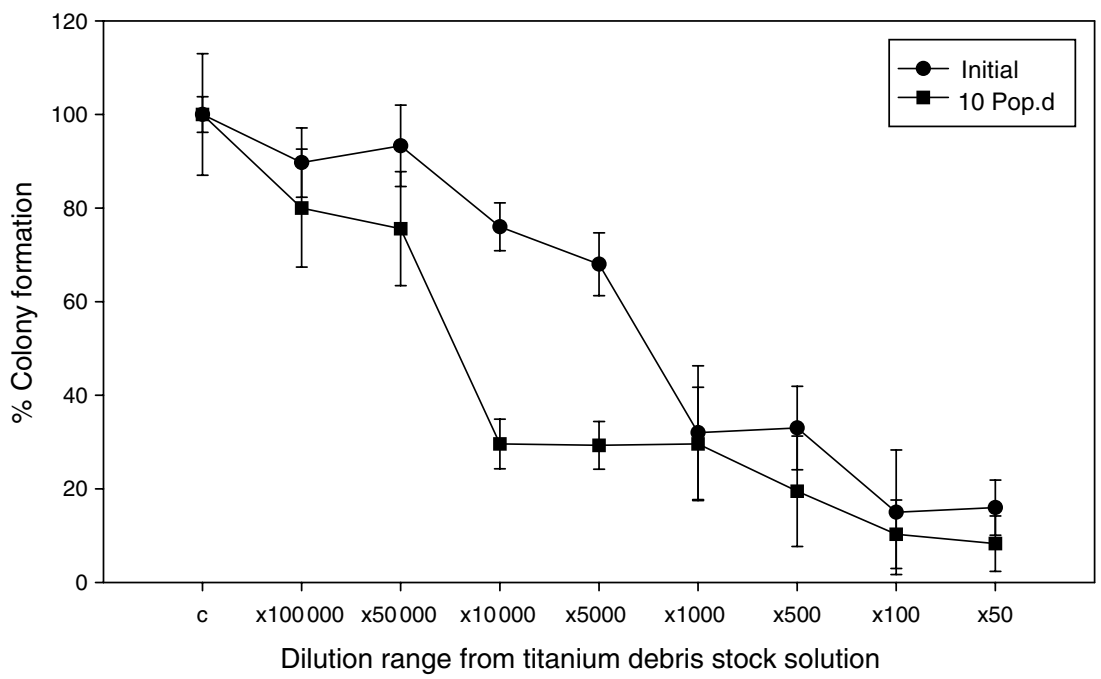

Figure I The initial survival curve reflects the percentage survival with respect to colony formation of HF 9 cells exposed to titanium debris for $24 \mathrm{~h}$. The percentage survival of the progeny of these cells (these cells were not treated) was examined 10 population doublings postexposure to titanium debris. All values were expressed as a percentage of control where control was expressed as $100 \%$.

\section{DISCUSSION}

It has been well established that some metals, which are used in metal implants, have carcinogenic potential to humans when exposure occurs in their ionic form and via other routes (IARC, 1987). It has yet to be established whether metals used in metal prosthesis in particulate form have themselves the capability to cause malignant transformation of cells. This paper provides direct evidence that titanium obtained from a metal prosthesis can induce characteristics that are associated with genomic instability in the progeny of treated primary human cells. The genomic instability demonstrated in this study is marked by a reduced clonogenic survival in the progeny of treated cells 10 population doublings postexposure and a persistent level of cytogenetic abnormalities.

The clonogenic analysis demonstrates lethal mutations/delayed reproductive death in the progeny of cells treated with titanium debris. This expression of damage is similar to earlier observations that a wide range of chemicals could reduce the reproductive integrity of progeny cells for many generations following the initial acute exposure (Mothersill et al, 1998; Coen et al, 2001). It was observed from the clonogenic analysis that the titanium debris dilutions, which produced no apparent cytotoxicity to the initially exposed cells, allowed the survival of populations of cells, which are more prone to exhibit reproductive failure during subsequent cell divisions. For example at 1:10000 dilution factor of titanium debris, almost $70 \%$ of the cells survive to express the genomic instability phenotype compared with less than $30 \%$ after treatment with $1: 100$ dilution. At the $1: 10000$ dilution factor the progeny shows over $50 \%$ reduction in survival compared to the initial acute toxicity, whereas 1:100 dilution only shows less than $10 \%$ reduction compared to initial acute toxicity. Cells appear quite normal initially and show no evidence of increased cytogenetic abnormalities or reproductive failure. However for several generations of division postexposure, they begin to show high levels of nonclonal cytogenetic aberrations and reproductive failure. Consequently, low-dose exposure may have important consequences. This has been observed for all agents tested so far which show inducible genomic instability. The mechanism of induction and transmission of these effects is unknown but persistent oxidative stress has been documented in murine haemopoietic cells (Clutton et al, 1996). The perpetuation of the observed insidious damage expressed in an 'in vivo' situation may 
be prompted by the induction of reactive oxygen species. Metal prosthesis may elicit an inflammatory response whereby macrophages accumulate at the site of injury (Black and Hastings, 1998). During phagocytosis the macrophages generate highly reactive oxygen metabolites. This increase in production of superoxide anion and hydroxyl radicals as well as released lysomal hydrolyses by activated macrophages may augment cellular damage (Anderson and Miller, 1984). These oxidative species may also oxidise titanium peroxy compounds that eventually degrade into titanium dioxide and hydrogen peroxide (Overgaard et al, 1998). Further decomposition of hydrogen peroxide and titanium oxide creates the highly detrimental hydroxyl radical and superoxide (Tengvall et al, 1989; Klinger et al, 1997).

It has been hypothesised by Mothersill et al (1996) that lethal mutations/delayed reproductive death represents a sort of 'cleansing mechanism' removing unrepaired damage in the genome. Evidence for this has been obtained by Mothersill et al (1999) who examined cells from genetically different mice, which were previously shown to have different susceptibilities to cytogenetic instability (Watson et al, 1997). This study revealed that in the susceptible mice there was a low level of both early and delayed cell death (necrosis and apoptosis) in exposed cultures following irradiation, but in the mice that were resistant to the induction of cytogenetic instability, there was a high initial and delayed level of cell death. This strongly suggests that the death end points of genomic instability are acting to remove damaged cells from the proliferative population. In this study low-dose exposure allows greater survival of cells to express damage, reflected by the low cloning efficiency in the progeny of these cells. Thus, the delayed reproductive death observed is a measure of damage induced by titanium debris. Failure to respond to this damage by death increases the probability that the unstable cell will survive and divide. These results are very similar to those ascertained by this group for chemical carcinogens and radiation (Mothersill et al, 1998; Coen et al, 2001).

From the cytogenetical analysis it can be observed that the frequency of aberrations is elevated compared to control, most of these are of the unstable type arising de novo. These values are lower compared to results obtained for radiation (Kadhim et al, 1997) but they show a definite trend towards genomic instability. Like radiation, heavy metals induce stress responses and proteins such as metallothionein are upregulated (Duesburg and Rasnick, 2000). These protect cells from damage by these insults by inducing repair pathways and eliminating individual cells by apoptosis. The lower frequencies of persistent damage in metaltreated cells compared to radiation-treated cells may relate to metallothionein proteins that specifically deal with metal toxins. The cytogenetical analysis shows a phenomenon that is not seen postexposure to radiation, which is the persistent induction of tetraploidy. It has been postulated that such ploidy changes destabilise the karyotype leading to a tumorigenic karyotype (Duesburg et al, 1998; Duesburg and Rasnick, 2000). It is also known that tetraploidy may lead to immortalisation of cells 'in vitro' and to transformation during the process of carcinogenesis (Duesburg and Rasnick, 2000). These observations lead us to speculate that although conditions 'in vitro' are different to those 'in vivo', particulate debris from metal prostheses might leave the patient susceptible to carcinogenic initiation. A two-fold increase in chromosomal translocations was observed in patients with metal on plastic total hip replacements undergoing revision arthroplasty compared with those at primary arthroplasty (Doherty et al, 2001). Higher rates of chromosomal aberrations were observed in local bone-marrow cells adjacent to the prosthesis at revision surgery compared with bone marrow from the iliac crest from the same patient (Case et al, 1996). These aberrations mainly consisted of chromatid breaks. In some cancer incidence studies, it has been observed that there were increased incidences of lymphomas and leukaemia in patients with prosthetic joint replacements, but there were decreased incidences of breast, colon and rectum cancer (Gillespie et al, 1988; Visuri and Koskenvao, 1991). These studies were followed up over a 10 -year period postoperative procedure, which probably explains the significant increase in the short latency-type haematopoietic cancers. The latency period for particulate-induced solid tissue malignancy could take up to 20 years or more to manifest itself. Mechanical implantation or inhalation of metal dust may proceed to neoplastic transformation by a chemical route after corrosion or by aggregation of corrosion products around the implant or remote sites (Black and Hastings, 1998). Cytogenetic analysis also showed the induction of endoreduplication. This is where the cells undergo two DNA syntheses without cell division intervening (Aardema et al, 1998) and its occurrence may provide a mechanistic explanation for the induction of tetraploidy by titanium debris. High frequency of tetraploidy is associated with malignant melanoma and lymphoma (Satoh et al, 2000). Results from this paper revealed significant increases in the induction of tetraploidy in the fibroblast cell after a brief exposure to 1 in 500 dilution of the titanium debris.

In conclusion, this preliminary evaluation of particulate titanium debris from metal prosthesis has revealed that corrosion debris induce significant changes in treated cells to cause a measurable response. Increased levels of chromosomal aberrations and tetraploidy as well as lethal mutations/delayed reproductive death were observed in cells treated with titanium debris and their progeny. This damage was expressed for up to 10 population doublings postexposure for lethal mutations/delayed reproductive death and 15 population doublings postexposure for chromosomal instability. This study demonstrated that once the stimulus is removed the damage persists for many cell population doublings. In both animal and human studies, neoplastic transformation requires some time to pass between exposure (initiation) and manifestation of neoplastic transformation (Hennig et al, 1992). In humans, the latency period is typically 15-20 years and may be as long as 40 years (Black, 1999). Thus, the appearance of metal carcinogenesis in humans may be awaiting the passage of unelapsed latency period in the large number of younger patients who have received implants. This highlights the need for long-term epidemiological studies to determine the risks involved for young patients receiving surgical implants.

\section{ACKNOWLEDGEMENTS}

We acknowledge the support of the Irish Cancer Research Advancement Board who partly funded this work, and the Dublin Institute of Technology's Strategic Research and Development Graduate Recruitment Programme, that supported Natasha Coen.

\section{REFERENCES}

Aardema MJ, Albertini S, Arni P, Henderson LM, Kirsch-Volders M, Mackay JM, Sarrif DA, Taalman RDF (1998) Aneuploidy: a report of an ECETOC task force. Mutat Res 410: 3-79

Anderson JA, Miller KM (1984) Biomaterial biocompatibility and the macrophage. Biomaterials 5: 5-10
Black J (1999) Biological Performance of Materials: fundamentals of Biocompatibility, 3rd edn. New York and Basel: Marcel Dekker Inc.

Black J, Hastings G (1998) Handbook of Biomaterial Properties. London: Chapman \& Hall 
Breen DJ, Stoker DJ (1993) Titanium lines: a manifestation of metallosis and tissue response to titanium alloy megaprostheses. Clin Radiol 47: 274-277

Bullough PG (1994) Metallosis. J Joint Bone Surg (Br) 76(5): $701-712$

Case CP, Langkamer VG, Howell RT, Webb J, Standen G, Palmer M, Kemp A, Learmonth ID (1996) Preliminary observations on possible premalignant changes in bone marrow adjacent to worn total hip arthroplasty. Clin Orthop 329: S269-279.

Case CP, Langkamer VG, James C, Palmer MR, Kemp AJ, Heap PF, Solomon L (1994) Widespread dissemination of metal debris from implants. J Bone Joint Surg 76-B(5): 701-712

Clutton SM, Townsend KM, Walker C, Ansell JD, Wright EG (1996) Radiation induced genomic instability and persisting oxidative stress in primary bone marrow cultures. Carcinogenesis 17: 1633-1639

Coen N, Mothersill C, Kadhim M, Wright EG (2001) Heavy metals of relevance to human health induce genomic instability. J Pathol 194

Doherty AT, Howell RT, Ellis LA, Bisbinas I, Learmonth ID, Newson R, Case CP (2001) Increased chromosome translocation and aneuploidy in peripheral blood lymphocytes of patients having revision arthroplasty of the hip. J Bone Joint Surg 83B(7): 1075-1081

Doherty AT, Lewis B, Howell RT, Langkamer G, Case CP (2002) Wear debris from adjacent to fail total hip arthroplasty induces metal specific aberrations in the in vitro macronucleus assay. Mutagenesis (in press)

Duesburg P, Rasnick D (2000) Aneuploidy, the somatic mutation that makes cancer a species of its own. Cell Motility Cytoskeleton 47: $81-107$

Duesberg P, Rauch C, Rasnick D, Hehlmann R (1998) Genetic instability of cancer cells is proportional to their degree of aneuploidy. Proc Nat Acad Sci USA 95: 13692 - 13697

Gillespie WJ, Frampton CMA, Henderson RJ, Ryan PM (1988) The incidence of cancer following total hip replacement. J Bone Joint Surg 70-B(4): $539-542$

Hennig FF, Raithel HJ, Schalles KH, Dohler JR (1992) Nickel-, chrom-, and cobalt-concentrations in human tissue and body fluids of hip prosthesis patients. J Trace Elements Electrolytes Health Dis 6: $239-243$

IARC (1987) IARC Monographs on the Evaluation of Carcinogenic Risks to Humans, Supplement 7, Overall Evaluation of Carcinogenicity: An Updating of the IARC. Monographs Vol. 1-42

Jacobs JJ, Skipor AK, Doorn PF, Campbell P, Schmalzried TP, Black J, Amstatz HC (1996) Cobalt and chromium concentrations in patients with metal on metal total hip replacements. Clin Orthop Relat Res S329: S256-S263

Jacobs JJ, Skipor AK, Patterson LM, Hallab NJ, Paprosky Black J, Galante JO (1998) Metal release in patients who have had primary total hip arthroplasty. J Bone Joint Surg, 80-A(10): 1447-1458

Kadhim MA, Lorimore SA, Townsend KMS, Goodhead DT, Buckel VI, Wright EG (1995) Radiation induced genomic instability: delayed cytogenetic aberrations and apoptosis in primary human bone marrow cells. Int J Radiat Biol 57: $287-293$

Kadhim MA, MacDonald DA, Goodhead DT, Lorimore SA, Marsden SJ, Wright EG (1992) Transmission of chromosomal instability after plutonium alpha-particle irradiation. Nature 355: 738-740

Kadhim MA, Marsden SJ, Wright EG (1997) Radiation-induced chromosomal instability in human fibroblasts: temporal effects and the influence of radiation quality. Int J Radiat Biol 73(2): 143-148
Kadhim MA, Walker CA, Plumb MA, Wright EG (1996) No association between p53 status and $\alpha$-particle-induced chromosomal instability in human lymphoblastoid cells. Int J Radiat Biol 69(2): 167 - 174

Klinger A, Steinberg D, Kohavi, Sela MN (1997) Mechanisms of adsorption of human albumin to titanium in vitro. J Biomed Mater Res 36: $387-392$

Langkamer VG, Case CP, Heap P et al (1993) Systemic distribution of wear debris after hip replacement: a cause for concern. J Bone Joint Surg Br 74B: $831-839$

Lyng FM, O’Reilly S, Seymour CB, Mothersill CE (1996) Morphological evidence of radiation induced delayed apoptosis in the distant progeny of irradiated cells. Radiat Environ Biophys 35: 237-283

Maloney WJ, Smith RL, Castro F, Schurman DJ (1993) Fibroblast response to metallic debris in vitro. Enzyme induction, cell proliferation and toxicity. J Bone Joint Surg 75(1): 835-834

Merritt K, Brown SA (1996) Distribution of cobalt chromium wear and corrosion products and biological reactions. Clin Orthop Relat Res 32S: S233 - S243

Mothersill C, Crean M, Lyons M, McSweeney J, Mooney R, O'Reilly J, Seymour CB (1998) Expression of delayed toxicity and lethal mutations in the progeny of human cells surviving exposure to radiation and other environmental mutagens. Int J Radiat Biol, 74(6): 673-680

Mothersill C, Harney J, Lyng F, Cottell D, Seymour CB (1995) Primary explants of normal human uroepithelium show an unusual response to low doses of cobalt60 gamma rays. Radiat Res 142: $177-183$

Mothersill C, Lyng F, O'Reilly S, Harney J, Seymour CB (1996) Expression of lethal mutations is suppressed in neoplastically transformed cells after treatment of normal cells with carcinogens. Radiat Res 145: 714-721

Mothersill CE, O’Mally KJ, Murphy DM, Seymour CB, Lorimore SA, Wright EG (1999) Identification and characterization of three subtypes of radiation response in normal human urothelial cultures exposed to ionizing radiation. Carcinogenesis 20(12): 2273-2278

O'Reilly S, Mothersill C, Seymour CB (1994) Postirradiation expression of lethal mutations in an immortalized human keratinocyte cell line. Int Radiat Biol 66(1): $77-83$

Overgaard L, Danielsen N, Bjursten LM (1998) Anti-inflammatory properties of titanium in the joint environment. J Bone Joint Surg $80 \mathrm{~B}(5)$ !QJ;888-893

Puck TT, Marcus PI (1956) Action of X-rays on mammalian cells. J Exp Med 103: $653-666$

Satoh S, Hashimoto-Tamaoki T, Furuyama J, Mihara K, Namba M, Kitano Y (2000) High frequency of tetraploidy detected in malignant melanoma of Japanese patients by fluorescence in situ hybridization. Int J Oncol 17(4): $707-715$

Seymour CB, Mothersill C, Alper T (1986) High yields of lethal mutations in somatic mammalian cells that survive ionising radiation. Int J Radiat Biol 50: $167-169$

Tengvall P, Lundstrom I, Sjoqvist L, Elwing H (1989) Titanium-hydrogen peroxide interaction: model studies of the influence of the inflammatory response on titanium implants. Biomaterials 10: 166-175

Visuri T, Koskenvao M (1991) Cancer risk after Mckee-Farrar total hip replacement. Orthopaedics 14(2): $137-142$

Watson GE, Lorimore SA, Clutton SM, Kadhim KA, Wright EG (1997) Genetic factors influencing alpha-particle-induced chromosomal instability. Int J Radiat Biol 71(5): 497-503

Watson GE, Lorimore SA, Wright EG (1996) Long-term in vivo transmission of $\alpha$-particle-induced chromosomal instability in murine haemopoietic cells. Int J Radiat Biol 69(2): 175-182 